\title{
Fruit Waste and Sugarcane Bagasse as Potential Natural Resources of Mineral and Lipophilic Substances
}

\author{
Sonia Patricia Ordonez ${ }^{1}$, Crispin Humberto García-Cruz ${ }^{1}$, Mauricio Boscolo ${ }^{2}$ and Jesús Eliécer Larrahondo ${ }^{3}$ \\ 1. Department of Engineering and Technology of Food, São Paulo State University (UNESP), IBILCE, Campus of São Jose Do Rio \\ Preto, São Jose Do Rio Preto, CEP 15000, Brazil1 \\ 2. Department of Chemistry and Environment Science, São Paulo State University (UNESP), IBILCE, Campus of São Jose Do Rio \\ Preto, CEP 15000, Brazil \\ 3. Department of Chemistry, Santiago Cali University. Santiago de Cali 760035, Colombia
}

\begin{abstract}
The objectives of this study were to explore alternatives for using fruit waste and sugarcane bagasse as important sources for new products and potential applications in the food industry. Fast foods are part of modern life, as well as sources for producing biofuels based on biomass. The mineral content and compounds of nutritional interest, such as lipophilic substances, were determined in fruit waste (orange peels, passion fruit, bananas, grapes) and sugarcane bagasse. Significant differences were found in the samples tested, where minerals, such as potassium, nitrogen, zinc and iron, were found in fruit residues (bananas, oranges, passion fruit) and sugarcane bagasse. Banana residues were the most important source of minerals, followed by orange peels. Gas chromatography mass spectrography (GC-MS) analyses of the lipophilic fractions obtained from the plant residues revealed the presence of mostly saturated (palmitic, stearic) and unsaturated (oleic and linoleic) fatty acids, as well as other nutritionally valuable compounds, such as antioxidants (flavones in orange residues). The residues studied here can be used for future research to optimize pretreatment and hydrolysis of biomass for bioethanol production.
\end{abstract}

Key words: Biomass, fruit waste, minerals, lipophilic substances, sugarcane bagasse.

\section{Introduction}

In 2010, Brazil produced 42 million tons of fruit with significant harvests of oranges, bananas, coconut and pineapple (annual productions of 18.1, 7.0, 2.9 and 2.5 million tons, respectively), as well as grapes and passion fruit on a smaller scale [1, 2]. This large variety of tropical fruits has an excellent international market (711,000 tons exported from Brazil in 2013) due to the country's excellent climate, geographical position and soils [3].

Fruit processing includes juice extraction and production of pulp and sweets for human consumption. By-products and waste materials consist mainly of peels, seeds and other agricultural residues, whose composition may vary from crop to crop. Their

Corresponding author: Sonia Patricia Ordonez, Ph.D. student, research field: food and engineering science. potential use as biomass includes the production of biofuels, such as bioethanol, other products of interest to the food industry and the emerging animal nutrition market [2]. For example, 12 tons of oranges produce about 1.2 tons of waste [4]. Brazil has increased its production of passion fruit to 664,000 tons [5], generating $70 \%$ residue. Given the presence of pectin in the peels, lipids (fatty acids) and minerals, this residue has great potential for use in small ruminant diets. The grapes processed by the wine industry have residues that are also rich in phenolic compounds, antioxidants and potassium, comparable to other fruits grown in Brazil, such as pomegranate (Punica granatum L.) [6, 7]. For example, daily diets in small ruminants should include $5.2 \mathrm{~kg}$ of carbohydrates during a dry season [6].

Sugarcane bagasse in the form of lingocellulosic biomass merits special mention for producing 
bioenergy and bioethanol (second generation), especially due to the presence or formation of an inhibitor substance for the fermentation process. The harvest of the year 2015, which covers an estimated 9 million hectares of land, projected a production of 659.1 million tons of cane and about 38.3 million tons of sugar [8]. The bagasse, which represents 25\%-30\% of the processed sugarcane, is a high-energy-value by-product and an important input for producing compounds or products (for example, 1,4-dicarboxilic acids, xylitol, feed products, plastics, etc.) with added value due to its contents of residual sugars, cellulose, hemicellulose, lignin and lipophilic materials, such as waxes and fatty acids [9].

Bananas are consumed domestically, and the residue which consists mainly of peels is disposed of or used for animal feed and composting on small farms. Each hectare of bananas generates approximately 220 tons of waste, consisting mainly of lignocellulosic materials. Given that only 3\% of banana production is industrialized in Brazil and $40 \%$ of its weight corresponds to peels and other residues (i.e., 83,000 tons of industrial waste), there is great potential for its use in producing biofuels and other valuable products in the chemical and food industries [10].

There is a need for chemical characterization of biomass, such as fruit waste and sugarcane bagasse with respect to the food industry, animal nutrition and biofuel production, especially bioethanol, because these studies canprovide valuable information about minerals and organic substances for better selection of waste materials and pretreatment of biomass as potential natural resources.

\section{Materials and Methods}

Peels and residues from fruits-oranges, bananas (Musa cavendischii), grapes, passion fruit (Passiflora edulis Sims) and sugarcane bagasse were collected from the São Jose do Rio Preto market and studied under laboratory conditions of the Department of Engineering and Technology of Food at the
UNESP-IBILCE campus. The samples were dried at $70{ }^{\circ} \mathrm{C}$ in a vacuum oven for $48 \mathrm{~h}$, milled and followed by acid digestion. Then, $0.5 \mathrm{~g}$ samples were heated with sulfuric acid at $350-400{ }^{\circ} \mathrm{C}$ for 2 h. Mineral analyses were performed by atomic absorption (analytic equipment Jena model contrA ${ }^{\circledR}$ 300) according to the method described by Malavolta et al. [11]. Nitrogen, potassium, phosphorus, calcium, magnesium, iron, manganese, copper and zinc content were determined in each sample.

Lipophilic substances of each plant material were collected by Soxhlet extraction with hexane-acetone (1:1). The resulting lipid fractions were analyzed by gas chromatography mass spectrometry (GC-MS) after derivatization with $\mathrm{N}, \quad \mathrm{O}$-bis (trimethylsilyl-trifluoroacetamide) (BSTFA). The GC-MS analyses were done with Agilent 5975C VL GC/MSD system with 7890A, with an HP-5 ms capillary column. The optimal operating conditions were as follows: injector temperature-230 ${ }^{\circ} \mathrm{C}$; injector volume $-1 \mu \mathrm{L}$; oven $-100{ }^{\circ} \mathrm{C}$ for $1 \mathrm{~min}$. The temperature was elevated at a rate of $10{ }^{\circ} \mathrm{C} / \mathrm{min}$ until reaching $250{ }^{\circ} \mathrm{C}$, and then elevated at the rate of $15^{\circ} \mathrm{C} / \mathrm{min}$ until $295{ }^{\circ} \mathrm{C}$ (global time-26 min). Gas carrier-helium was used during the analyses (flux of $1.5 \mathrm{~mL} / \mathrm{min})$.

Each sample (1-10 mg) was treated with an excess of the silylating reagent (2:1 ratio) after evaporation of the hexane-acetone extracting solventin a rotary vacuum evaporator.

\section{Results and Discussion}

Except for phosphorus, all the other elements had statistically significant differences between the fruit residues and sugarcane bagasse (Tables 1-3). Potassium had the highest values (0.41\%-3.73\%) in all samples, while the banana residues had the highest potassium content (3.73\%), followed by passion fruit and grape residues. With respect to the minor elements, significant differences in iron and manganese were observed among the samples 
analyzed, where the highest values were found in the bagasse (637 mg/kg Fe), followed by grape (93.0 $\mathrm{mg} / \mathrm{kg} \mathrm{Fe}$ ) and banana residues (85.6 $\mathrm{mg} / \mathrm{kg} \mathrm{Fe}$ )

(Table 2).

Table 1 Major mineral contents of fruit residues and sugarcane bagasse (dry matter).

\begin{tabular}{|c|c|c|c|c|c|}
\hline \multirow{2}{*}{ Sample } & \multicolumn{5}{|c|}{ Mineral content (\%) } \\
\hline & $\mathrm{N}$ & $\mathrm{P}$ & $\mathrm{Ca}$ & $\mathrm{K}$ & $\mathrm{Mg}$ \\
\hline Bagasse & $0.47 \pm 0.02$ & $0.11 \pm 0.13$ & $0.13 \pm 0.04$ & $0.41 \pm 0.01$ & $0.13 \pm 0.02$ \\
\hline Bananas & $1.28 \pm 0.05$ & $0.11 \pm 0.01$ & $0.21 \pm 0.01$ & $3.73 \pm 0.13$ & $0.19 \pm 0.004$ \\
\hline Passionfruit & $0.84 \pm 0.03$ & $0.06 \pm 0.01$ & $0.17 \pm 0.01$ & $2.35 \pm 0.23$ & $0.13 \pm 0.006$ \\
\hline Oranges & $1.11 \pm 0.02$ & $0.05 \pm 0.01$ & $0.63 \pm 0.01$ & $1.41 \pm 0.08$ & $0.12 \pm 0.017$ \\
\hline Grapes & $0.97 \pm 0.04$ & $0.13 \pm 0.01$ & $0.22 \pm 0.01$ & $2.25 \pm 0.08$ & $0.13 \pm 0.029$ \\
\hline
\end{tabular}

Table 2 Minor mineral contents of fruit residues and sugarcane bagasse.

\begin{tabular}{lllll}
\hline \multirow{2}{*}{ Sample } & \multicolumn{4}{c}{ Mineral content $(\mathrm{mg} / \mathrm{kg})$} \\
\cline { 2 - 5 } & $\mathrm{Fe}$ & $\mathrm{Mn}$ & $\mathrm{Cu}$ & $\mathrm{Zn}$ \\
\hline Bagasse & $637.40 \pm 18.90$ & $78.20 \pm 2.70$ & $7.30 \pm 0.02$ & $24.90 \pm 5.10$ \\
Bananas & $85.60 \pm 1.90$ & $9.50 \pm 0.50$ & $7.10 \pm 0.11$ & $48.20 \pm 0.09$ \\
Passionfruit & $53.90 \pm 6.30$ & $4.80 \pm 0.14$ & $1.90 \pm 0.06$ & $13.50 \pm 0.92$ \\
Oranges & $27.80 \pm 3.90$ & $8.10 \pm 0.11$ & $2.00 \pm 0.04$ & $7.50 \pm 0.08$ \\
Grapes & $93.00 \pm 10.80$ & $11.20 \pm 1.30$ & $6.00 \pm 0.09$ & $30.60 \pm 2.10$ \\
\hline
\end{tabular}

Table 3 Statistical analysis of average content of some minerals in fruit waste and sugarcane bagasse.

\begin{tabular}{lllllllll}
\hline \multirow{2}{*}{ Sample } & \multicolumn{7}{c}{ Average content of minerals } \\
\cline { 2 - 10 } & $\mathrm{N} \mathrm{( \% )}$ & $\mathrm{P}(\%)$ & $\mathrm{Ca}(\%)$ & $\mathrm{K}(\%)$ & $\mathrm{Mg}(\%)$ & $\mathrm{Mn}(\mathrm{mg} / \mathrm{kg})$ & $\mathrm{Zn}(\mathrm{mg} / \mathrm{kg})$ & $\mathrm{Cu}(\mathrm{mg} / \mathrm{kg})$ \\
\hline Bananas & $1.28^{\mathrm{a}}$ & $0.11^{\mathrm{a}}$ & $0.21^{\mathrm{b}}$ & $3.73^{\mathrm{a}}$ & $0.19^{\mathrm{a}}$ & $9.50^{\mathrm{bc}}$ & $48.20^{\mathrm{a}}$ & $7.14^{\mathrm{b}}$ \\
Oranges & $1.11^{\mathrm{b}}$ & $0.05^{\mathrm{a}}$ & $0.63^{\mathrm{a}}$ & $1.40^{\mathrm{c}}$ & $0.12^{\mathrm{b}}$ & $8.10^{\mathrm{c}}$ & $7.500^{\mathrm{e}}$ & $2.00^{\mathrm{d}}$ \\
Grapes & $0.97^{\mathrm{c}}$ & $0.13^{\mathrm{a}}$ & $0.22^{\mathrm{b}}$ & $2.25^{\mathrm{b}}$ & $0.13^{\mathrm{b}}$ & $11.20^{\mathrm{b}}$ & $30.6^{\mathrm{b}}$ & $6.00^{\mathrm{c}}$ \\
Passionfruit & $0.84^{\mathrm{d}}$ & $0.06^{\mathrm{a}}$ & $0.17^{\mathrm{c}}$ & $2.35^{\mathrm{b}}$ & $0.13^{\mathrm{b}}$ & $4.80^{\mathrm{d}}$ & $13.40^{\mathrm{d}}$ & $1.90^{\mathrm{d}}$ \\
Bagasse & $0.47^{\mathrm{e}}$ & $0.11^{\mathrm{a}}$ & $0.13^{\mathrm{d}}$ & $0.41^{\mathrm{d}}$ & $0.12^{\mathrm{b}}$ & $78.20^{\mathrm{a}}$ & $24.90^{\mathrm{c}}$ & $7.30^{\mathrm{a}}$ \\
\hline
\end{tabular}

${ }^{\mathrm{a}-\mathrm{e}}$ Means same letters from different samples in the same columns are not significantly different $(P<0.05)$ (Duncan's test).

All minerals have several roles in human and animal biochemistry and physiology. These minerals (Tables 1 and 2) are essential in the human diet [12]. Many are co-factors for different enzymes, so their incorporation in the products based on biomass is essential. Although fruit residues supply a minor proportion of the total mineral requirements of human and animal nutrition, they could be an important source for developing potential foods and nutraceutical products or as key factors in the fermentation process of bioethanol from yeast.

Plant lipids are a group of compounds, including short- and long-chain fatty acids, their free or esterified acylglycerols, waxes and steroids, such as sitosterol and the stigmasterol chain group. Although the accumulation of these compounds in large amounts in fruits and/or their waste is rare, their presence in seeds and some fruits is the basis of good nutrition and an important raw material in the food and cosmetics industry. The composition of major lipophilic compounds found in the waste of oranges, bananas, passion fruit, grapes and sugarcane bagasse is given in Table 4. Saturated fatty acids, such as palmitic acid and stearic acid, as well as unsaturated acids (linoleic and oleic acids) were found mainly in the banana and orange waste and sugarcane bagasse. These fatty acids, which are the most abundant in nature, are also commercially important compounds. With respect to other compounds, such as steroids, stigmasterol was found in almost all orange, passion 
fruit and banana waste, as well as in sugarcane bagasse. Aromatic compounds and potential antioxidant agents (flavone, vitamin E and methyl salicylate) were also detected by GC-MS in the lipophilic extracts of orange, passion fruit and grape waste (Table 4).

Table 4 Lipophilic compounds in fruit residues and sugarcane bagasse as determined by GC-MS.

\begin{tabular}{|c|c|c|c|c|c|c|}
\hline \multirow{3}{*}{$\begin{array}{l}\text { Sample } \\
\text { Bagasse }\end{array}$} & \multicolumn{6}{|c|}{ Compound (mg/g extract) } \\
\hline & Palmiticacid & Linoleicacid & Oleicacid & Estericacid & Arachidicacid & Stigmasterol \\
\hline & 2.60 & 10.70 & 7.4 & 20.00 & 1.10 & 0.42 \\
\hline \multirow{2}{*}{ Oranges } & Palmiticacid & Linoleicacid & Decanal & Estericacid & $\begin{array}{l}\text { Scutellarein } \\
\text { tetramethyl ether }\end{array}$ & Stigmasterol \\
\hline & 3.20 & 0.20 & 0.14 & 0.30 & 0.22 & 0.20 \\
\hline \multirow{2}{*}{ Passionfruit } & Palmiticacid & Coniferol & N-butylcitrate & Icosane & Vitamin E & Stigmasterol \\
\hline & 8.10 & 1.18 & 2.14 & 0.87 & 1.26 & 0.77 \\
\hline \multirow{2}{*}{ Bananas } & Palmiticacid & 1-butylbutyrate & Icosane & Estericacid & Squalene & Stigmasterol \\
\hline & 5.60 & 2.10 & 2.0 & 4.50 & 0.45 & 1.24 \\
\hline \multirow{2}{*}{ Grapes } & Palmiticacid & $\begin{array}{l}\text { Monoglyceride of } \\
\text { palmiticacid }\end{array}$ & Pentadecane & Methylsalicylate & Heptacosanol & Octadecanal \\
\hline & 2.60 & 22.90 & 1.2 & 0.26 & 9.60 & 1.00 \\
\hline
\end{tabular}

These results emphasize the need for further technical and economic studies in order to make better use of agricultural biomass, such as fruit waste, by identifying products of interest to the food industry, cosmetics and human health, as has been recommended by international organizations, such as the USDA [13].

\section{Conclusions}

Fruit wastes from bananas and oranges are an important source of minerals, such as potassium, nitrogen and other mineral elements that could be exploited as nutritional supplements in agriculture, nutraceuticals and animal feed.

The presence of fatty acids and other lipophilic compounds of commercial importance in fruit waste and sugarcane bagasse suggests the need for further studies to identify opportunities or products derived from this kind of biomass in order to produce compounds or new products with added value for the food and chemical industry, as well as their impact (positive or negative) on biofuel (bioethanol) production using natural resources, such as fruit waste and bagasse.

\section{References}

[1] Barros, Z. M. P. 2011. "Tropical Fruit Peels as A Source of Antioxidants for Enrichment Ready Juice.” M.Sc. thesis, School of Agriculture Luiz de Queiroz, São Paulo University, Piracicaba, Brazil. (in Portuguese)

[2] Da Cruz, S. S., Morais, A. B. F., Ribeiro, S. B., Oliveira, M. G., Da Costa, M. S., and Feitosa, C. T. 2013. "Waste of Fruit on Feeding Ruminant.” Article 222. 10 (6): 2909-31

[3] Fresh Plaza, Global Fresh Produce and Banana News. 2014. "Brazil’s Largest Exporter of Fruits.” Access time: May 9, 2014. www.freshplaza.es/article/82226.

[4] Carvalho, F. C. 1992. Availability of Agro-Industrial Wastes and Processing of Agricultural Products. São Carlos, SP: Embrapa/EU PAE, 7-28.

[5] Geografic and Statistic Institute from Brazil (IBGE). 2008. Agricultural Census: Accessed time Aug. 24, 2008, http://www.ibge.gov.br.

[6] Bevitori Kling de Moraes, E. H., Paulino, F. M., Valaclares, S., Kling de Moraes, K. A., Detmann, E., and Goncalves de Souza, M. 2010. "Nutritional Assessmen of Suplementation for Beef Cattle during the Dry Season.” $P$. Bras. Zootec. 39 (3): 608-16

[7] Barros, Z. M. P., Salgado, J. M., Melo, P. S., and Oliverisa-Biazotto, F. 2014. "Enrichement of Commercially-Prepared Juice with Pomegranate (Punicagranatum L.) Peel Extract as A Source of Antioxidants.” J. Food Research 3 (6): 179-87.

[8] Bernardes, W. 2014. "Latin America Leads the Production of Organic Sugar, Bio-Sugar.” International Magazine Procana, August, 2014.

[9] Larrahondo, J. E. 2015. The Sugar Process in Brief. Ed. Catorce. Cali, Colombia. 126. (in Spanish) 

Mineral and Lipophilic Substances

[10] Empresa Brasileira de Pesquisa Agropecuária. 2008. News from the Research Institute of Brazil. Sugarcane Productivity in Brazil from 1987-2008. Access time: August 2014. http://www.agencia.cnptia.embrapa.Br/agencia40/AGOI/ Abertura.html.

[11] Malavolta, E., Vitti, G. C., and De Oliveira, S. A. 1997. Evaluation of the Nutritional Status of Plants: Applications and Management, 2ed.. Piracaciba, SP,
Brazil: Brasilera Association for Research Potash, 319 (in Portuguese)

[12] Mayer, A. M. 1997. "Historical Changes in the Mineral Content of Fruits and Vegetables.” British Food Journal 99 (6): 207-11.

[13] United States Department of Agriculture (USDA). 2008. U.S. Bio-Based Products: Market Potential and Projections through 2025. USDA, Washington, DC, USA. 